\title{
Elaboração de um website sobre a memória histórica da educação em saúde no país
}

\author{
Thais Melo Farias*, Guilherme Ruan Ribeiro, Fábio Luiz Mialhe
}

\begin{abstract}
Resumo
O projeto de elaboração de um website sobre a memória histórica da educação em saúde no país teve como intuito contribuir, preservar e divulgar a memória histórica da educação em saúde bucal no Brasil. O objetivo da montagem do site foi auxiliar o máximo possível os estudantes e profissionais das áreas da saúde e historia a compreenderem como conteúdos educativos em saúde foram elaborados e divulgados através do tempo em nosso país. Foram digitalizados mais de 50 tipos de documentos (folders, folhetos, livros etc.) sobre o campo de educação e promoção em saúde e da saúde bucal, os quais foram produzidos no país desde o início do século XX, englobando temas sobre higiene, educação sanitária, educação em saúde e métodos educativos. Todos os materiais foram disponibilizados no site para acesso gratuito da população. Após o website ter sido colocado no ar, foi realizada uma pesquisa com 120 alunos do ensino médio a fim de avaliar sua qualidade. Todos acharam muito fácil/fácil a navegação pelo website, $91 \%$ acharam que o website foi montado de maneira lógica, de forma a facilitar o acesso às informações; e $74 \%$ acharam o site excelente. Conclui-se que o website foi bem avaliado por aqueles que o utilizaram e que suas informações servirão de grande ajuda àqueles que desejarem resgatar a memória histórica das atividades educativas em saúde e em saúde bucal desenvolvidas em nosso país.
\end{abstract}

\section{Palavras-chave}

Educação em saúde, História da Odontologia, História da Medicina

\section{Introdução}

A educação em saúde bucal é uma prática social desenvolvida no país, principalmente a partir do início do século XX. Entretanto, verifica-se, ainda, uma escassez de publicações, artigos e sítios na internet que apresentem a iconografia e os conteúdos relacionados aos materiais educativos desenvolvidos por órgãos oficiais, empresas e instituições de ensino sobre o assunto desde o início do século passado, dificultando o resgate do desenvolvimento histórico e a reflexão desta prática em nosso país. Assim, o presente projeto teve como objetivo elaborar um website sobre a memória histórica da educação em saúde geral e bucal no país, disponibilizando ao leitor informações sobre materiais educativos impressos (folders, cartazes, panfletos manuais) produzidos no país desde meados do século passado.

\section{Resultados e Discussão}

Foram digitalizados diversos tipos de documentos sobre o campo de educação e promoção em saúde e da saúde bucal sendo eles: folders, folhetos, livros entre outros, sobre temáticas como higiene, educação sanitária, educação em saúde e métodos educativos. Todos os materiais estão disponibilizados no website para acesso gratuito da população e pode ser acessado pelo endereço

http://www.fop.unicamp.br/index.php/pt-br/biblioteca-

virtual

Após o website ter sido colocado no ar, foi realizada uma pesquisa com 120 alunos do ensino médio a fim de avaliar a sua qualidade. Todos os respondentes acharam muito fácil/fácil a forma de navegação pelo website; 91\% dos participantes acharam que o site foi montado de maneira lógica, de forma a facilitar 0 acesso às informações; e 74\% acharam o site excelente.

\section{Conclusões}

Conclui-se que o website foi bem avaliado por aqueles que o utilizaram e que suas informações servirão de grande ajuda àqueles que desejarem resgatar a memória histórica das atividades educativas em saúde e em saúde bucal desenvolvidas em nosso país.

\section{Agradecimentos}

Á Universidade Estadual de Campinas e ao CNPq pelo apoio recebido.

\footnotetext{
${ }^{1}$ Pedro AR. Os museus portugueses e a Web 2.0. Ci. Inf 2010, 39, 92-100.

${ }^{2}$ Schweibenz W. Virtual museums: the development of virtual museums. ICOM News, 2004, 57, 3.

${ }^{3}$ Figueiredo, P.B.A; Souza M.V.; Ota, T.M.N.; Ribeiro, B.B.S. Efetividade de um website de educação em saúde bucal para adolescentes. Rev. Bras. Promoç. Saúde 2014, 27, 398-405.

${ }^{4}$ Cruz, D.I.; Paulo, R.R.D.; Dias, W.S.; Martins, V.F., Gandolf, P.E. O uso das mídias digitais na educação em saúde. Cad. FUCAMP. 2011,10, 130-42.
} 